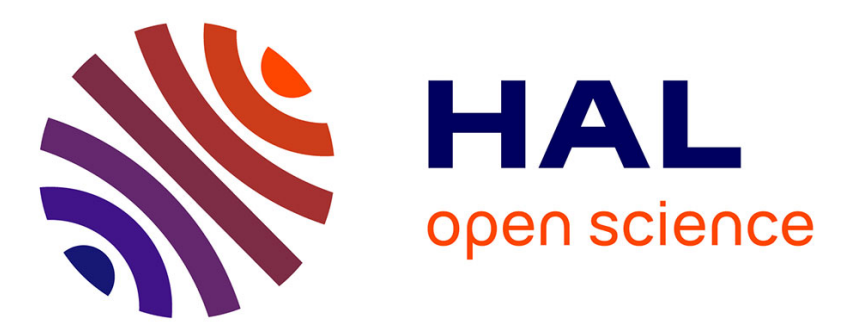

\title{
John Lever, Johan Fischer, 2018: Religion, regulation, consumption: globalising kosher and halal markets Anom Sigit Suryawan
}

\section{To cite this version:}

Anom Sigit Suryawan. John Lever, Johan Fischer, 2018: Religion, regulation, consumption: globalising kosher and halal markets: Manchester University Press, Manchester, 185 p.. Review of Agricultural, Food and Environmental Studies, 2019, 100 (1-4), pp.137-140. 10.1007/s41130-019-00088-6 . hal-02889957

\section{HAL Id: hal-02889957 https://hal.science/hal-02889957}

Submitted on 6 Jul 2020

HAL is a multi-disciplinary open access archive for the deposit and dissemination of scientific research documents, whether they are published or not. The documents may come from teaching and research institutions in France or abroad, or from public or private research centers.
L'archive ouverte pluridisciplinaire HAL, est destinée au dépôt et à la diffusion de documents scientifiques de niveau recherche, publiés ou non, émanant des établissements d'enseignement et de recherche français ou étrangers, des laboratoires publics ou privés. 


\title{
John Lever, Johan Fischer, 2018: Religion, regulation, consumption: globalising kosher and halal markets
}

\section{Manchester University Press, Manchester, 185 p.}

\author{
Anom Sigit Suryawan ${ }^{1}$ (D) \\ Published online: 1 July 2019 \\ C) INRA and Springer-Verlag France SAS, part of Springer Nature 2019
}

The rapid development of global kosher and halal markets in recent years has caught the attention of many agri-food scholars worldwide. The study of these religious markets offers fascinating intellectual endeavours in that it raises many important questions regarding, among others, the compatibility of religion and economy, institutionalisation and standardisation of religious dietary principles, and governance and regulation of religious markets in an era of globalisation. John Lever and Johan Fischer's new book, Religion, Regulation, Consumption: Globalising Kosher and Halal Markets, is one of the latest scholarly attempts to deal with these inquiries. In this book, Lever and Fischer explore the way by which kosher and halal markets have expanded globally as well as the consequences thereof. They explain these processes through a comparative study on the regulation, production, and consumption of kosher and halal food in two European countries i.e., the UK and Denmark. While this comparative method might appear challenging for many, Lever and Fischer successfully and convincingly execute this comparison. Drawing on rich empirical material, including interviews with the individual and household consumers, food manufacturers, certifiers, religious organisations, and state bureaucracies, the authors analyse the understandings and practices of kosher and halal principles at different levels of the social scale from a historical, political, and institutional perspective.

The book consists of five chapters, an introduction, and a conclusion. Each of these chapters is carefully themed and well composed, making it easy to follow the story and arguments therein. Lever and Fischer begin in Chapter 1 entitled "Kosher and halal in the UK and Denmark" with a historical overview of Judaism and Islam in the UK and Denmark over the past centuries and how it affects the development of kosher and halal markets in these countries. They discover that the long history and a large number of Jewish and Muslim communities settling in the UK have been a key factor in the establishment of state policies supporting stunned and non-stunned meat to be

Anom Sigit Suryawan

anom.sigit@gmail.com

1 Graduate School of Economics, Kyoto University, Kyoto, Japan 
marketed in the country. In turn, the UK kosher and halal markets continue to flourish to such an extent that the country becomes both a major supplier of and an important destination for kosher and halal products, especially to/from other European countries. On the contrary, the authors suggest that, due to a relatively small and more recent origin of Jewish and Muslim population in Denmark, the production of Danish kosher and halal products is more aimed at international markets, while the product options (particularly non-stunned meat) are limited in the domestic market.

In Chapter 2 entitled "Manufacturing and selling meat", Lever and Fischer examine power dynamics underpinning the production, certification, and retailing of kosher and halal meat. Here, the authors highlight how kosher and halal "quality" is defined and implemented by different certification bodies and religious authorities and how trust emerges and is maintained along the supply chain. They observe that in a highly standardised market, whether it is kosher or halal, trust is mediated through certificates and labels. Hence, the underlying process of qualification is ultimately based on transnational governmentality i.e., practices of supervision, auditing, and inspections by certification bodies and religious authorities. Subsequently, these non-state bodies gain increasing power and authority. The degree of control possessed by these actors, however, varies between kosher and halal markets. The rabbinical authorities in the kosher market maintain a relatively higher degree of control than the religious authorities in the halal market because the former is more centralised than the latter. Nevertheless, Lever and Fischer indicate that these power dynamics might move to new trajectories as large retail chains such as ASDA and Tesco increasingly assert their influence by dictating from where and from whom meat can be sourced.

In Chapter 3 entitled "Beyond meat", Lever and Fischer explore the struggles faced by the biotechnology industry in understanding and complying with kosher and halal requirements. The expansion of kosher and halal markets globally has brought new demands for biotech firms such as enzyme manufacturers, but it also comes with some challenges. Particularly, to be kosher/halal certified, companies are required to make necessary changes in the ingredients and work processes and guidelines that go into the production. Since these changes are highly technical and complex in nature, and at the same time the knowledge and understandings among inspectors are unequal, the decision on proper kosher/halal practice is often concluded through negotiation and compromises between inspectors and the company's representatives. As such, it was revealed that a longer and personalised relationship between these individuals plays a decisive role in making the certification process run smoothly. Here, Lever and Fischer invite the readers to pay attention to an anomaly in the kosher and halal certification process for the biotechnology industry; that is, on the one hand, the operation and organisation of biotech firms has become more auditable and rationalised because they are compelled to comply with standardised kosher/halal rules. On the other hand, the strict and complex kosher/halal requirements and intensified audit procedures, however, are often compromised and simplified during the negotiation process between the representatives of the company and certifiers. Therefore, Lever and Fischer contend that the need for human oversight in religion-based certification processes exemplifies how standardised religious dietary principles and practices only become compatible during inspections.

Lever and Fischer probe the issue on how Jewish and Muslim consumers understand and practice their everyday food consumption in Chapter 4 and 5 entitled "Kosher 
consumers" and "Halal consumers" respectively. The authors suggest there are many similarities between Jewish and Muslim consumers in the way they perceive, practice, and acquire knowledge about kosher/halal food. They argue that Jewish and Muslim consumers are generally fastidious about their food choices and share the common idea that kosher and halal food is good for their spiritual and physical wellbeing. The source of knowledge of these perceptions, unsurprisingly, comes from religious texts, rabbis and ulama, family and friends, and from websites and smartphone apps. Notwithstanding, these consumers remain unaware and uninterested with the intensifying, profitdriven ties between producers, sellers, and certifiers taking place behind the production of kosher and halal food. As Lever and Fischer observed, for most consumers, the increasing number of kosher and halal certified products is regarded as a good thing, and thus is desirable. Hence, their desire to take a closer look at both processes and consequences of the growing influence and control of market actors and religious authorities is overshadowed by their aspiration toward an improved availability of kosher/halal food in the market. The continuum of this process, the authors argue, might change the way consumers understand and practice their kosher/halal food, particularly how to judge what is and is not acceptable.

In the concluding section, Lever and Fischer present the main arguments of the book, which are organised around three keywords: religion, regulation, and consumption. First, the authors make a compelling claim that the expansion of kosher and halal markets is stimulated by religious expressions embedded in and through production, regulation, and consumption. As such, not only religion is compatible with market rationale, but actually fast-tracks the mainstreaming process of kosher and halal markets at the regional and global level. Second, transnational governmentality in the forms of standardisation, inspection, and certification has become the underlying regulating mechanisms in kosher and halal markets, which results in the growing power and authority of certification bodies and religious authorities. Third, the development of contemporary kosher and halal consumption, particularly in the Western societies, is paradoxical in the sense that, on the one hand, Jewish and Muslim consumers become more strict and cautious in their food understandings and practices, but on the other hand, remain unaware and relaxed with the consequences of the mainstreaming process of kosher and halal markets.

In sum, the book is a welcome addition for researchers and students in the field of anthropology, sociology, and international political economy who are interested in the development of religious markets. The biggest strength and value of the book arguably lie in its overarching theoretical approaches combined with vigorous ethnographic evidence. An array of current theories and concepts in social sciences, such as transnational governmentality, ethnography of encompassment, audit culture, and compound practice, are well knitted to capture both the 'bigger picture' (macro level analysis) and day-to-day relationships (micro level analysis) underpinning the production, regulation, and consumption of kosher and halal food. Also, samples of cases are rich and carefully selected and sufficiently elaborated, making the book a valuable methodological reference to study global processes.

Areas of limitation in this book are few but worth noting. First, the authors' claim that large retailers gain increasing power in the UK halal markets remains short in empirical evidence. How are meat suppliers and certifiers disciplined by these retailers, and how do they deal with it? Answers to these questions will clarify the extent to 
which retailers become powerful actors. Second, the criteria by which consumers can be categorised as unaware and unconcerned with transnational governmentality processes in kosher and halal markets are not clearly defined. In some places, the authors put emphasis on consumers' lack of knowledge in the increasing number of products (i.e. enzymes) being kosher/halal certified, but in other parts they refer to the politics behind kosher/halal certification (e.g. transparency issues). Although the authors cannot go wrong with either way, I think focusing on the latter would likely lead to a more fruitful intellectual journey as it can reveal how transnational governmentality is legitimised or undermined. Lastly, the contribution of the book to the existing literature is relatively weak because almost all of the arguments are already documented elsewhere. In fact, a large part of the book, particularly related to halal markets, are redundant materials taken from the authors' previous work (Bergeaud-Blackler et al. 2015; Fischer 2016), making the book look more a reworked than a fresh production.

\section{References}

Bergeaud-Blackler, F., Fischer, J., \& Lever, J. (2015). Halal matters: Islam, politics and markets in global perspective. New York: Routledge.

Fischer, J. (2016). Islam, standards, and technoscience. In Global Halal Zones. London: Routledge.

Publisher's note Springer Nature remains neutral with regard to jurisdictional claims in published maps and institutional affiliations. 